AperTO - Archivio Istituzionale Open Access dell'Università di Torino

\title{
Sociology of the Families
}

\section{This is a pre print version of the following article:}

Original Citation:

\section{Availability:}

This version is available http://hdl.handle.net/2318/1661833

since 2018-03-10T15:19:39Z

\section{Publisher:}

Cambridge University Press

Published version:

DOI:10.1017/9781316418376.029

Terms of use:

Open Access

Anyone can freely access the full text of works made available as "Open Access". Works made available under a Creative Commons license can be used according to the terms and conditions of said license. Use of all other works requires consent of the right holder (author or publisher) if not exempted from copyright protection by the applicable law. 


\section{Part VII}

\section{SOCIAL INSTITUTIONS}




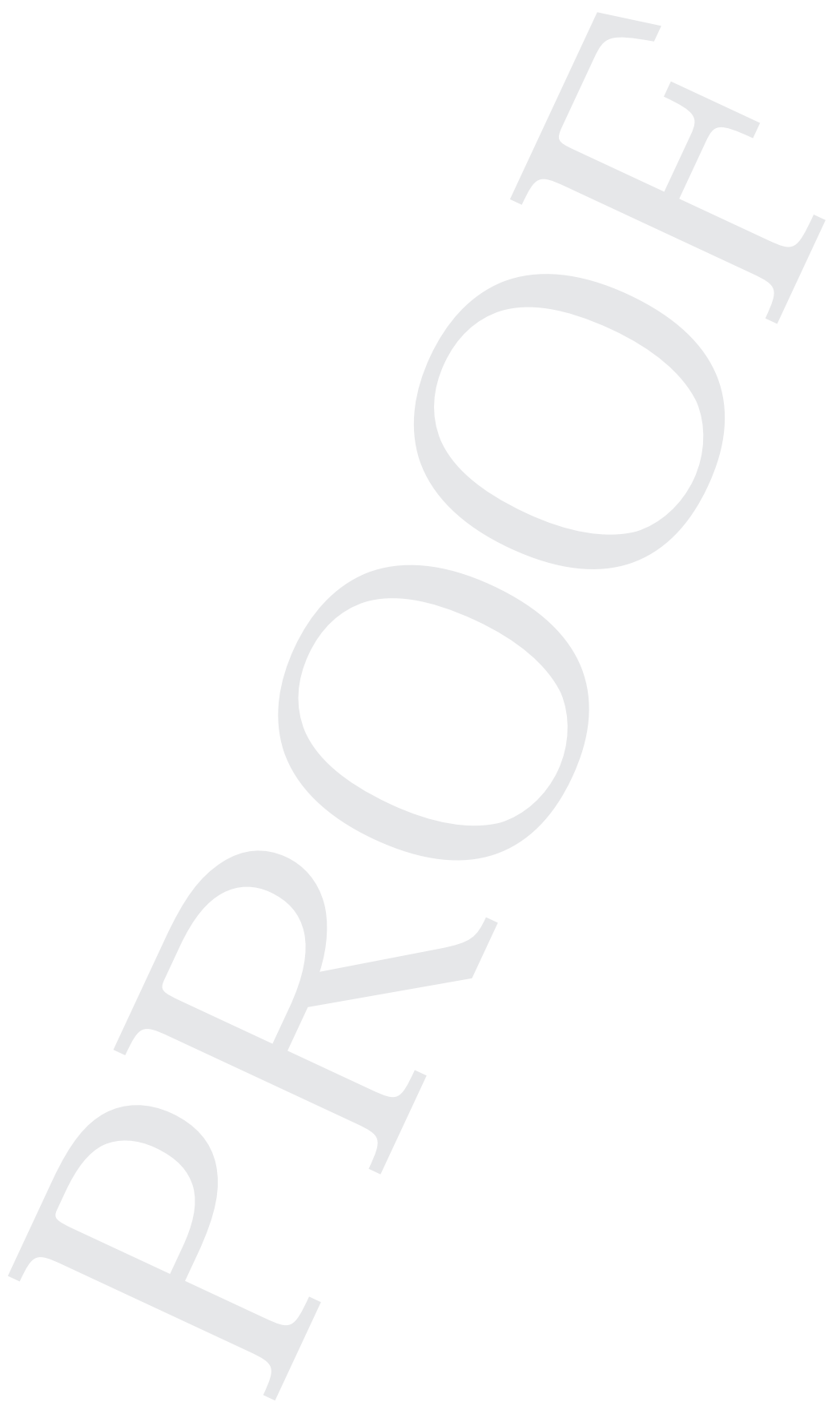




\section{CHAPTER 28 The Sociology of Families}

Contrary to most students' expectations, "the family" is not an easy topic to study. Having grown up in a family (as most people have), we think we know what a family is, even if we cannot always offer a precise definition, and it can be tempting to generalize from our own experiences. Yet the family is not a straightforward topic.

The family is society's most common, best-known physical, relational, and symbolic space, It is in the context of family relationships, as they are socially defined and regulated, that life's defining events and processes are translated into individual experience: birth and death, growing up, growing old, sexuality and procreation (Saraceno and Naldini 2013). As we shall see, the family is also a privileged arena for the social construction of reality.

One factor that makes the family difficult to study is the strong emotions it elicits. The family is seen as something very unique - the key arena for one's personal development and relationships. The notion of family is also intertwined with religious and moral beliefs. Since the family is bound up with relationships and events connected to the deeper, more universal aspects of human life, it is a source of material for constructing social archetypes, myths. It is no coincidence that in recent decades "family values" have become a central issue in political debates in various Western governments, from Italy to America (Skolnick and Skolnick 2010; Saraceno and Naldini 2013). The current state of the family is constantly being compared to the ways families used to be, a mythical past ("the good old days") that represents unity and solidity. Lastly, when studying the family today, the contemporary images of family as shelter, as a setting for close bonds and intimacy, coexist and contrast with images of the family as an arena of oppression, obligations, and egotism: the family as a creator of monsters. In the media, and also in people's minds, these contradictory images often coexist side by side.

What all these different ideas and images of the family have in common, despite their contradictions, is on one hand their ahistorical nature, and on the other the fact that they all appear to be based on a vision of the family that can be traced as such in 
every social and historical context as "the family."

\section{A Sociological Approach to Family Research}

The study of the family is interdisciplinary and multifaceted: genetics, physiology, psychology, history, anthropology, sociology, economics all touch on it (Skolnick and Skolnick 2010). Since the family is a core institution in all societies, it has interested influential sociological theorists, including Karl Marx, and various founding fathers of sociology, such as Frédéric Le Play, Friedrich Engel, Emile Durkheim and Max Weber. "The family" that pioneering sociologists were interested in was "the family" as an institution - a set of institutional arrangements used by a specific society to organize and perform various tasks, in this case reproduction, child rearing, and care and emotional support.

The French sociologist Frédéric Le Play (1907[1871]), one of the first scholars to study the family, maintained that the family was the most important source of social control and socialization in society. Durkheim (1888) building off Le Play's work, wrote Introduction à la sociologie de la famille in 1888. In 1902, Friedrich Engels wrote The Origin of the Family, Private Property and the State and Economy and Society. A couple of decades later, Max Weber (1922) examined the separation between the family economy and the market economy as a crucial transition in the development of capitalism.

Sociology has since progressed and developed in various directions which include the sociology of the family. The sociological study of the family was influenced by three main theoretical and conceptual approaches during the twentieth century, at least up until the 1960s (Nock 1992). First and foremost, the structural-functionalist approach, and in particular, Talcott Parsons, was responsible for establishing sociology as a science. For Parsons, the family serves two essential functions in modern society: the socialization of children and the stabilization of the adult personalities of the population of society that could create problems for society if not controlled. The second approach used in the sociological study of the family, the social exchange approach, compares the family to the market and views bonds and family relationships as based on costs and rewards. Lastly, the symbolic interaction framework focuses on the human ability to create and use symbols. Theorists using this perspective note that the family is built physically and symbolically on the interaction among its members.

As a subfield, the sociology of the family has gradually developed, albeit at different rates and to different extents in different countries, in parallel with the development of sociology as a discipline. History, demography, anthropology, psychology and economics have made fundamental contributions to the sociology of the family and influence how this subfield responds to various fundamental questions such as: What is a family? Where do its boundaries lie? Given the multiple meanings and experiences contained in what we call family, and the interdisciplinary nature of the subject, it is useful to explore the main innovations in the sociology of the family from a number of different perspectives. In particular, since the 1970s, significant contributions have come from historical studies and women's studies.

\section{The Historical Perspective}

Historical family studies provide key lessons for studying the family from a sociological perspective. Though families are a universal social institution, their forms vary greatly across time and space. Philippe Ariès published his first book on social history and everyday life in 1962, and Peter Laslett and the Cambridge Group (Laslett and Wall 1972) published their historical family demography studies in 1972 . Their work and that of other historians show the variety of family experiences in the past and 
illustrate the impossibility of tracing a unified historical path of "the family" (Anderson 1980). Studying different forms of family is an important step toward understanding the way in which different societies and social groups ascribe various meanings to their world, their place in time and space, and their social relationships as they go about organizing their daily lives and establishing bonds and alliances. Industrialization, for example, affected Japanese and English families in different ways. It also had different effects on the families of craftsmen and those of aristocrats, rural families and the urban bourgeoisie, families in Spain and families in other European countries (Goode 1970).

From historical studies, the sociology of the family has borrowed one important lesson, namely that the family is a social construct, rather than a "natural" phenomenon. Goran Therborn (2004), in his research on the changes in the family around the world in recent centuries, writes that the organization of the family, both from a normative perspective (i.e., ideal models) and in terms of actual practices, always represents a balance that is historically and socially situated between sexual relationships and generational relationships (both of which are also power relationships). It is a balance that is forged in response to "internal" needs (childrearing, reproduction, support), but also external circumstances (the economic, demographic, and political scenario).

\section{Women's Studies and Gender Studies}

Another important innovation in family sociology was the epistemological rift opened by women's studies in the 197os. During that period, the women's movement introduced the "women's point of view," thus heralding a new perspective from which the family could be studied and investigated (Saraceno 1980). In particular, the women's point of view enabled a move away from the vision that had dominated the sociological field up till then, namely functionalism. The work of Talcott Parsons and Robert Bales (1956) clearly takes the division of labor between men and women within the nuclear family for granted. It was (and often still is) assumed that the family was the "natural" arena for women's lives: their main or even sole focus. Women's studies critiqued this vision, bringing a new perspective to the sociology of the family.

In a 1984 essay, the American scholar Barrie Thorne identified the main areas affected by what she calls the "feminist rethinking of the family." In the first place, the new perspective challenged the vision of the family as a homogeneous, harmonious entity, organized around functions and roles agreeably divided between men and women, parents and children (as the functionalists asserted). It also highlighted the sociohistorical nature of gender relations, which, along with generational lines, structure both the family and more generally the social division of labor. Lastly, it underlined the need to study the boundaries and interdependencies between the family and society, and acknowledge the tensions that affect both the family experience and its critique.

From the feminist perspective, the family was viewed as the arena, par excellence, of differences. It is in the family that one's sex becomes a social destiny, implicitly or explicitly regulated. It is in the family that it is decided who can have sex with whom and who cannot. The social processes and social structure that create and uphold differences (to the point of producing gender inequalities) contribute to the social construction of gender. To emphasize how this construction operates on multiple levels, Risman (2004) refers to gender as a "social structure." According to Risman, gender is a social structure because it differentiates between opportunities and constraints according to sex on three different levels: (1) on the individual level, in the development of gendered selves; (2) on an interactional (cultural level), since men and women have different cultural expectations even when they fill positions that are structurally identical; and (3) on an institutional level, where explicit regulations regarding the distribution of resources and material goods are gender specific. In addition to 
gender, the other element of differentiation in the family is, of course, the generation to which one belongs.

\section{Generations, Time and Life Course}

The changes between the generations within a family over time are a source of both continuity and an element for differentiating experiences, interests, and breaking down or redefining family boundaries. Children, and the changes that they bring as they are born, grow up, move out, get married, etc. create constant changes in the family, marking the various stages in the lifecycle, and shifting the boundaries between the immediate family and the broader network of kinship.

The focus on children, and generations and intergenerational changes in particular, developed thanks to the advent of the life course theoretical perspective in family research.

This perspective, with its emphasis on multiple, social contexts (Elder 1994), focuses on the social and historical circumstances in which families are embedded. By examining the changes in the relationships between generations, as per Elder's seminal work Children of the Great Depression (1974) scholars began to study transformations in the family as powerful indicators of social change.

The study of the family from the life course perspective suggests that the nature of intergenerational families and their patterns of interaction and relationships are closely linked to changes in economic, demographic, and social circumstances over time. Time is therefore an important element when it comes to analyzing the family (Haraven 2001), not only in the sense of historical time, and the social changes due to the advent of successive cohorts, but also in the sense of life time, i.e. individual and family life cycles or life courses. Combining the concept of cohort (i.e., a horizontal group that shares the same position in social/historical processes) with the vertical concept of generation, referring to descent group (the family tree) and position within the family (grandparents, parents, and children), highlighted the need for a model that takes into account both the long-term consequences of behaviors deployed by a specific cohort (e.g., the long-term effects of the reproductive practices of a specific cohort of women) and the changes in the generational relationships within the family (such as the "new" role of grandparents in the twentieth century). The family, an eminently historical phenomenon, therefore also has its own internal history, which constantly transforms both the rules and modes of the relationships between the sexes and the generations, and the interchanges between family and society.

The interactions between family and society offer another important key for interpreting the family, which, as we will see below, provides insight into the dynamics of change within the family, and also the aspects of the interchange itself.

\section{Key Aspects in the Contemporary Study of Family Changes}

The sociology of the family explores the changes in the family and family life, the interdependencies between the family and society, and the dynamic relationship between family and social change (demographic, cultural, economic, and the changing forms of public regulation). These dynamic relationships reveal both the persistent and the relentless work of interpretation, transformation, and redefinition that goes into constructing and experiencing the family, both on the micro-level of individual experience, and the macro-level of society. In the context of these complex processes of exchange, there are a number of key topics which I believe play a crucial role in contemporary processes of defining and redefining the family, as well as highlighting the differences between different countries. In addition to the conceptual and methodological issue of defining the family, there are three particularly significant family research topics: the reconfiguration 
of marriage, work/family life balance, and the advent of assisted reproductive technologies.

\section{Defining the Family: New Configurations}

One of the major issues for scholars of sociology of the family regards the question of "what is a family?" As we will see, this is primarily a question of boundaries. "What is a family?" is the question that opens many of the discipline's textbooks. How can we distinguish between the household (as a residential unit) and the family (as a setting for relationships)?

The issue of demarcating the scope of inquiry, namely identifying the residential unit and relational space of the household, as distinct from both broader kinship network and non-family households, has plagued historians, demographers, and anthropologists without a solution ever being reached. The problem concerns the criteria used to define the boundaries: the criteria for spatial and relational aspects, exchanges, and sharing. Fundamental contributions in this direction have come from scholars belonging to the Cambridge Group (Laslett and Wall 1972), using the historical family demography approach mentioned above. They highlighted the need to take account not only the criteria of cohabitation but also the biological and legal ties that bind the members of a household: bonds of consanguinity and affinity, descent, and marriage. From this point of view, the structure of the family (household) is defined by the way in which the members lie along vertical and horizontal axes, representing sexual and generational relationships respectively. Different types of families have been identified, starting from the nuclear family. Yet, as comparative studies have revealed (Hantrais and Letablier 1996; Hantrais 2004), the question of how to delimit the household and the family remains unsolved, especially when it comes to making comparisons over time and space. Institutional and statistical definitions vary considerably by country and over time in individual nations.
The second key issue, in both conceptual and methodological terms, is that of tracing the boundaries of the family with respect to kinship. How can we distinguish between the household/family and the system of kinship? These are indeed shifting boundaries, given that the dividing lines between the family, namely the household, and relatives/kin, represent one of the main factors of change in the structure of the family across its life-cycle. New people enter the family, bringing new relatives with them. On the other hand, there is the rise in "new" families that comes with the increase in the number of couples cohabiting, divorcing, remarrying, and bearing children outof-wedlock, and the introduction of samesex marriage, and the rise of reproductive technologies - all of which complicate the issue of family/kinship boundaries.

\section{Marriage in Transition}

For centuries, marriage represented the main institution in the family for granting role positions to individuals within the gender framework according to their sex and for establishing filiation and parenthood. With marriage now less dominant as a social institution in most western countries, and the existence of alternative patterns through adulthood and in other life stages, we need to talk about "families" in the plural sense, rather than the singular of "the family." Marriage has also undergone a process of de-institutionalization, that is, a progressive weakening of the social norms which govern the partners' behavior (Cherlin 2004). This process is the result of different phenomena, including the increase in the number of cohabiting couples and the advent of same-sex marriage. Marriage is no longer the dominant institution of the family. Moreover, the change in its meaning, including the fact that it is now seen as optional and reversible, is crucial when it comes to understanding the changes underway in couple relationships and in forms of becoming parents and of being children.

In particular, over the last fifteen years, the introduction of same-sex marriage has 
subverted the norms that regulate marriage from the inside, and at the same time has changed the ways in which the family is both defined and created. In the first place, by acknowledging that same-sex relationships are couple relationships with the status of family, the ways in which filiation and parenthood can be achieved - from a legal and social standpoint - have increased. In fact, most of the countries which recognize same-sex marriage also acknowledge the right of same-sex couples to adopt. In some countries, same-sex couples can also make use of medically assisted procreation techniques. It can therefore be said that in the wide historical, social, and cultural repertoire of ways/modes of "being" a family, the advent of same-sex marriage in the twenty-first century shows yet again that there is nothing "natural" about the family. The removal of the distinction among legitimate and illegitimate children, the advent of adoption, and the legal differences between countries in the rules governing the assisted reproduction techniques, highlight the way in which legal, social, and even religious norms contribute to constructing the family and establishing which relationships of gender and generation can be part of it and which cannot.

\section{The Advent of Reproductive Technologies}

Assisted reproductive technologies extending the ways in which people can have a child and multiplying the ways in which the status of parent or child can be achieved - are one of the most significant new features in the twenty-first century family. At the same time, relationships between parents and children are being radically redefined, due to the introduction of DNA testing, giving children new opportunities to discover their biological origins, and making it more difficult for fathers to shirk their parenting responsibilities. Studying these new technologies can provide insight into the continually shifting boundaries between the "natural" sphere of reproduction and the social sphere of production and reproduction of family and kinship.

\section{Family and Work}

To make sense of the changes taking place in contemporary families we need to understand the interplay between ineluctable social forces, such as the rise of the postindustrial economy, with the increase of job insecurity, and the efforts of individuals, families, and societies to craft innovative solutions to the dilemmas created by (incomplete) family (gender) changes. Out of all the changes in women's lives in recent decades, the most significant is the dramatic increase in the number of women in paid work. This has led to one of the most significant changes in family life in the last forty years. In addition to the decline of the male breadwinner led family, which was the ideal, and the prevalent family model (Lewis 2001), and the increase in the number of women in paid work, other changes have taken place in the family. Marital instability has increased, as has the number of single-parent families, blended families, and remarriages. Marital instability has made gender division in the family more risky than in the past for women and children. Meanwhile, the increasing number of women in paid employment has made it less viable (Naldini and Saraceno 2013).

In spite of these changes in the family and the labor market, several factors point to the enduring tensions encountered by mothers (and fathers) when it comes to combining family life and work. Indeed, research on gender and the division of care and paid work has shown that most of the changes in the gender system in recent decades have entailed women taking up positions and activities previously restricted to men, while few changes have occurred in men's lives. There continues to be a highly unequal division of housework between men and women, because men's participation has changed very little. As has been observed, the changes in women's participation in the labor market have not put an end to what Hochschild (1989) calls the "second shift" 
of housework that comes at the end of the working day. The incomplete transformation of gender relations (Esping-Andersen 2009) thus remain an "unfinished" (gender) revolution because the changing lives of men and women come up against resistant institutions (Gerson 2010). Social policies have not kept pace with changing economic patterns that require women to work in the paid workforce.

\section{Conclusion}

The family has been a key topic for sociology since the days of the founding fathers. The ways in which people view and build families, and the variety of experiences and types of family life, are powerful indicators of the specific society and of social change. The sociology of the family also benefited from the contributions of related disciplines (history and demographics, first and foremost) and other perspectives (firstly women's studies, then gender studies).

In this chapter I have taken an interdisciplinary view of the sociology of the family, selecting approaches that enabled us to distance ourselves from the "obviousness" of the family as a topic of study and the various ideological discourses that accompany it. These approaches help us to identify a number of dimensions of family life, focusing on the connections and the interdependencies between the family and other arenas of social change, such as technology and the world of work. I have shown how the family is a complex social actor, embedded in multiple interactions with society.

Families influence us so profoundly that it is difficult to overstate their importance. Yet their power to shape our lives depends on their connections with other institutions. Families are shaped by the societies they inhabit, but they also have the power to transform those societies. In recent years, this has led to the study of different types of families, such as French or American or Swedish families; urban or rural families; families in the north or south; workingclass or middle-class families, rather than "the family." To use a metaphor coined by an American academic (Thorne 1982), the family can be seen as a fabric of different threads that make up a pattern. If you add or remove a thread, the pattern changes and if you detect a thread that was previously hidden, or had escaped your notice, your whole perception of the pattern changes.

\section{References}

Anderson, Michael. 1980. Approaches to the History of the Western Family, 1500-1914. London: Macmillan.

Ariès, Philippe. 1962. Centuries of Childhood: A Social History of Family Life. New York, NY: Vintage Book.

Cherlin Andrew, J. 2004. The Deinstitutionalization of American Marriage. Journal of Marriage and Family 66: 848-861.

Durkheim, Emile. 1888. Introduction à la sociologie de la famille. Annales de la faculté du lettres du Bordeaux. 10: 257-282.

Elder, Glen, L. 1974. Children of the Great Depression. Chicago. IL. University of Chicago Press.

Elder, Glen, L. 1994. Time, Human Agency and Social Change: Perspectives on the Life Course. Social Psychology Quarterly 57: 4-15.

Engels, Friedrich. 2010. The Origin of the Family, Private Property and the State and Economy and Society. New York, NY: Penguin Classics.

Esping-Andersen, Gosta 2009. The Incomplete Revolution. Adapting to Women's New Roles. Cambridge: Polity Press.

Gerson, Kathleen. 2010. The Unfinished Revolution. How a New Generation is Reshaping Family, Work, and Gender in America, Oxford: Oxford University Press.

Goode, William J. 1970. World Revolution and Family Pattern. New York, NY: Free Press.

Hantrais, Linda and Marie T. Letablier. 1996. Families and Family Policies in Europe. London and New York, NY: Longman.

Hantrais, Linda. 2004. Family Policy Matters. Responding to Family Change in Europe, Bristol: Polity Press.

Haraven, Tamara. K. 2001. Historical Perspectives on Aging and Family Relations. In Handbook of Aging and the Social Sciences. Edited by R. H. Binstock and L. K. George. San Diego, CA: Academic. 
Hochschild, Arlie.1989. The Second Shift: Working Parents and the Revolution at Home. London: Piatkus.

Laslett, Peter and Richard Wall. eds. 1972. Household and Family in Past Time, Cambridge: Cambridge University Press.

Le Play, Frédéric. 1907[1871]. The Organization of the Family: According to the True Model Indicated by the History of All Races and of All Times. $5_{\text {th }}$ edn. Tours: Mame.

Lewis, Jane. 2001. The Decline of the Male Breadwinner Model: Implications for Work and Care. Social Politics. 8: 152-170.

Nock, Steven. 1992. Sociology of the Family. 2nd edn. Englewood Cliffs, NJ: Prentice Hall.

Parsons, Talcott and Robert F. Bales. 1956. Family Socialization and Interaction Process. London: Routledge and Keagan Paul.
Risman, Barbara. 2004. Gender as a Social Structure. Theory Wrestling with Activism. Gender and Society 18: 429-450.

Saraceno, Chiara and Manuela Naldini. 2013. Sociologia della famiglia. 3 rd edn. Bologna: il Mulino.

Saraceno, Chiara. 1980. Il lavoro maldiviso. Bari: De Donato.

Skolnick, Arlene S. and Jerome H. Skolnick. 2010. Family in Transition. 16th edn. Upper Saddle River, NJ: Pearson Education Company.

Therborn, Goran. 2004. Between Sex and Power. London: Routledge.

Thorne, Barry. ed. 1982. Rethinking the Family. New York, NY: Longman.

Weber, Max. 1978[1922]. Economy and Society: An Outline of Interpretive Sociology. Berkeley, CA: University of California Press. 